\title{
PERLINDUNGAN HUKUM BAGI ANAK PELAKU TINDAK PIDANA
}

\author{
Emi Puasa Handayani, Widodo Hariawan \\ 1. Universitas Islam Kadiri, Kediri \\ 2. Pengadilan Negeri Kediri \\ Email: wdd.hariawan@gmail.com
}

\begin{abstract}
ABSTRAK
Penelitian yang berjudul "Perlindungan Hukum bagi Anak yang melakukan Tindak Pidana" ini bertujuan ntk menganalisis terhadap faktor penyebab anak melakukan tindak pidana dan menganalisis bentuk perlindungan hukum terhadap anak pelaku tindak pidana. Metode pendekatan ini adalah yuridis normatif, serta analisis bahan hukum yang di pergunakan dalam penelitian jurnal ilmiah ini adalah analisis yuridis kualitatif yaitu analisis yang mendasar atau tertumpu pada penalaran hukum (legal reasoning), intrepesi hukum (legal intepretation), dan argumentasi hukum (legal argumentation) dengan secara runtut. Hasil penelitian dan pembahasan menunjukan bahwa faktor penyebab terjadinya anak melakukan tindak pidana adalah faktor ekonomi, faktor pendidikan, faktor lingkungan, faktor lemahnya penegakan hukum dan juga faktor dari kelalaian orang ta dalam mendidik anak.

Dapat disimpulkan bahwa terdapat faktor internal maupun eksternal yang sekaligus menjadi penyebab terjadinya seorang anak melakukan tindak pidana yaitu : 1) Faktor Internal merupakan faktor faktor yang berasal dari dalam diri anak itu sendiri, yang meliputi : salah asuhan, salah didikan dari orang tua sehingga anak menjadi manja atau sebaliknya dan lemahnya mental pada diri anak tersebut, faktor dalam berkumpul dengan teman dan sebagainya; 2) Faktor Eksternal merupakan faktor keluarga, faktor lingkungan sekolah, faktor lingkungan pergaulan dan sebagainya. Perlindungan hukum bagi anak yang tertang dalam pasal 34 Undang-undang Dasar tahun 1945 yang menegaskan bahwa "Fakir miskin dan anak-anak terlantar di pelihara oleh Negara". Hal ini menunjukan bahwa perhatian serius bagi pemerintah terhadap hak-hak anak dan perlindungannya, terutama bagi anak pelaku tindak pidana. Perlindungan bagi anak pelaku tindak pidana harus benarbenar di perhatikan secara serius. Perlindungan hukum tersebut meliputi beberapa konsep yaitu : 1) Konsep Restorative Justice, yaitu sebuah proses dimana semua pihak yang berkepentingan dalam pelanggaran tertentu bertemu bersama untuk menyelesaikan secara bersama-sama bagaimana menyelesaikan akibat dari pelanggaran tersebut demi kepentingan masa depan; 2) Konsep Diversi, yaitu suatu pengalihan penyelesaian kasus-kasus anak yang diduga melakukan tindak pidana tertentu dari proses pidana formal ke penyelesaian damai antara tersangka/terdakwa/pelaku tindak pidana dengan korban yang difasilitasi oleh keluarga dan/atau masyarakat, Pembimbing Kemasyarakatan Anak, Polisi, Jaksa atau Hakim.

Kata Kunci : Perlindngan Hukum, Pelaku Tindak Pidana Anak
\end{abstract}

\section{A. PENDAHULUAN}

Bahwa Indonesia sebagai Negara Pihak dalam Konvensi Hak Hak anak (Convention on The Right of Children) yang mengatur prinsip perlindungan hukum terhadap anak mempunyai kewajiban untuk memberikan perlindungan khusus terhadap anak yang berhadapan dengan hukum. ${ }^{1}$ Dengan demikian Negara Indonesia merupakan salah satu dari negara negara yang telah meratifikasi konvensi hak anak (Convention on The Right of Children). Dengan

\footnotetext{
1 Undang Undang Republik Indonesia Nomor 11 Tabun 2012 Tentang Sistem Peradilan Pidana Anak. hal. 1
}

dasar ratifikasi konvensi hak anak, Negara Indonesia memiliki kewajiban untuk memenuhi hak-hak bagi semua anak tanpa terkecuali, salah satunya mengenai hak anak yang perlu mendapat perhatian dan perlindungan hukum bagi anak yang berkonflik dengan hukum.

Pemerintah dalam rangka untuk mengantisipasi terjadinya tindak pidana yang dilakukan oleh anak dalam bentuk perlindungan hukum, maka pemerintah menerbitkan aturan perundang-undangan khususnya undang-undang perlindungan kepentingan anak, baik dalam bentuk formil maupun materiil. Upaya ini merupakan suatu 
langkah yang sangat tepat, dan memadai ditengah keterbatasan upaya memberikan perlindungan hukum bagi anak pada umumnya agar terhindar dari ekploitasi bermotif ekonomi dari korban tindak pidana lainnya dan anak sebagai pelaku tindak pidana. Kitab Undang-Undang Hukum Acara Pidana Nomor 8 Tahun 1981 secara umum tetap masih diberlakukan dalam proses penyidikan dan penuntutan perkara tindak pidana anak sepanjang tidak diatur oleh Undang-undang secara khusus. Di dalam Undang-undang Nomor 11 Tahun 2012 Tentang Sistem Peradilan Pidana Anak, Undang-undang ini menentukan bahwa peradilan anak dalam kompetensi absolute berada dalam lingkup Peradilan Umum. Bentuk pemberian perlindungan hukum yang dimaksudkan guna memberi kesempatan kepada anak agar menjadi manusia yang memiliki tanggungjawab di masa depannya, juga bagi nusa, bangsa dan negara, dikarenakan mungkin tindak pidana yang dilakukan anak bukan semata-mata perbuatan sadar namun karena faktor pengaruh lingkungan atau faktor emosional. Dikarenakan peradilan masuk dalam lingkungan Pengadilan Umum, maka apabila terjadi perkara yang terdakwanya anak maka dapat ditunjuk Hakim khusus untuk menangani dan mengadili anak pelaku tindak pidana.

\section{B. METODE PENELITIAN Jenis Penelitian}

Jenis penelitian ini adalah penelitian yuridis normatif, yaitu dengan mengunakan peraturan perundang-undangan. Titik berat penelitian yuridis normatif, sesuai dengan karakter keilmuan hukum yang khas, terletak pada telaah hukum atau kajian hukum terhadap hukum positif, yang meliputi tiga lapisan keilmuan hukum, terdiri atas telaah dogmatika hukum.

Pada tataran dogmatika hukum, pengkajiannya dilakukan terhadap identifikasi dalam hukum positif, khususnya undangundang. Sedangkan pada tataran teori hukum dilakukan telaah terhadap teori-teori yang dapat digunakan. Jenis penelitian Jurnal Ilmiah ini, merupakan penelitian yuridis normatif yang mengkaji secara kritis dan komprehensif mengenai Perlindungan Hukum anak yang melakukan tindak pidana.

\section{Pendekatan Masalah}

Pendekatan masalah yang dipergunakan dalam suatu penelitian akan menggunakan beberapa pendekatan, yakni pendekatan peraturan perundang-undangan (statute approach), pendekatan konseptual (conceptual approach), pendekatan historis (bistorical approach), dan pendekatan kasus (case approach) Perlindungan Hukum anak yang melakukan tindak pidana. Pendekatan peraturan perundang-undangan (statute approach) digunakan, karena yang akan diteliti adalah aturan hukum yang berkaitan dengan penelitian ini. Pendekatan ini dilakukan dengan menelaah semua peraturan perundang-undangan yang terkait dengan Perlindungan Hukum anak pelaku tindak pidana. Pendekatan konseptual (conceptual approach), merupakan pendekatan penelitian, yang bertitik tolak pada pandangan dan doktrin yang berkembang dalam ilmu hukum. Dengan melihat pandangan dan doktrin tersebut, akan ditemukan pengertianpengertian hukum, serta konsep-konsep hukum, sesuai dengan permasalahan atau materi muatan hukum yang akan diteliti. Dengan pendekatan konsep ini, diharapkan dapat membuat argumentasi hukum guna menjawab materi muatan hukum yang menjadi titik tolak penelitian.

Pendekatan historis (bistorical approach), dilakukan mengetahui latar belakang lahirnya aturan perundangundangan. Pendekatan kasus (case approach) dalam penelitian normatif bertujuan untuk memahami penerapan norma-norma hukum yang diterapkan dalam praktik hukum. Pendekatan kasus dilakukan dengan cara telaah terhadap kasus yang telah diputus yang bertalian dengan permasalahan baik pada tingkat judex factie maupun putusan yang telah memiliki kekuatan hukum tetap.

\section{Bahan Hukum}

Dalam penelitian ini mempergunakan bahan hukum primer dan bahan hukum sekunder, sebagai berikut:

1) Bahan hukum primer

a. Undang-Undang Dasar 1945

b. Undang-Undang Nomor 11 Tahun 2012 tentang Sistem Peradilan Pidana Anak.

2) Bahan hukum sekunder

Bahan hukum sekunder, yaitu

bahan hukum yang memberikan 
penjelasan mengenai bahan hukum primer, seperti studi kepustakaan dan studi dokumentasi, arsip, data resmi pemerintah, buku-buku hukum, jurnal, majalah yang dipublikasikan yang berhubungan dengan penulisan Jurnal Ilmiah ini.

\section{Metode Pengumpulan Data}

Teknik pengumpulan dan pengolahan bahan hukum dalam penelitian Jurnal Ilmiah ini, diawali dengan studi kepustakaan, yaitu inventarisasi semua bahan hukum yang terkait dengan pokok permasalahan, baik bahan hukum primer, maupun bahan hukum sekunder. Kemudian diadakan klasifikasi bahan hukum yang terkait, selanjutnya bahan hukum tersebut disusun secara sistematis untuk lebih mudah membaca dan mempelajarinya. Bahan hukum yang diperoleh dari studi kepustakaan, kemudian dikumpulkan dan dikelompokkan, untuk dipilih dan dipilah sesuai dengan karakter bahan hukum yang diperiukan, terutama yang ada relevansinya dengan permasalahan yang dibahas. Untuk bahan hukum yang kurang relevan, untuk sementara disisihkan, dan akan dipergunakan apabila bahan hukum tersebut diperiukan.

\section{Analisis Data}

Analisis ini dilakukan dengan terlebih dulu mengidentifikasi bahan hukum yang terkumpul, kemudian didiskripsikan, disistematisasikan dengan mendasarkan pada teori keilmuan hukum dan konsep-konsep ilmu hukum, prinsip-prinsip atau asas-asas hukum. Selanjutnya, analisis bahan hukum yang dipergunakan dalam penelitian Jurnal Ilmiah ini adalah analisis yuridis kualitatif, yaitu analisis yang mendasarkan atau bertumpu pada penalaran hukum (legal reasoning), intepretasi hukum (legal intepretation), dan argumentasi hukum (legal argumentation) secara runtut. Penggunaan analisis bahan hukum yang demikian, diharapkan dapat menjelaskan permasalahan yang dirumuskan dalam penelitian Jurnal Ilmiah ini secara memuaskan.

\section{PEMBAHASAN}

\section{Faktor-Faktor Penyebab Anak Melakukan Tindak Pidana}

Kejahatan-kejahatan yang dilakukan oleh anak pada umumnya dilakukan karena kurang pemahaman terhadap hal yang baik dan buruk. Masa anak-anak adalah masa yang sangat rawan melakukan tindakan, karena masa anak-anak suatu masa yang rentan dengan berbagai keinginan dan harapan untuk mencapai sesuatu ataupun melakukan sesuatu. ${ }^{2}$ Suatu kejahatan, kenakalan atau perbuatan pidana yang dilakukan oleh seseorang pasti memiliki penyebab yang menjadi latar belakang mengapa perbuatan itu dilakukan. Faktor-faktor yang mendorong perbuatan itu dilakukan sering juga disebut sebagai motivasi dimana didalamnya mengandung unsur niat, hasrat, kehendak, dorongan kebutuhan, cita-cita yang kemudian diwujudkan dengan lahirnya perbuatanperbuatan, demikian pula perbuatan pidana yang dilakukan oleh anak tidak terlepas dari faktor yang mendukung anak yang melakukan perbuatan pidana. Menurut Kartini Kartono, perbuatan pidana yang dilakukan oleh anak terjadi disebabkan oleh beberapa faktor. Faktor tersebut dibedakan dalam dua kelompok besar yaitu:

\section{A. Faktor Internal}

Faktor pendorong yang meliputi beberapa hal yaitu :

a. Untuk memuaskan kecenderungan keserakahan.

b. Meningkatkan agresifitas dan dorongan seksual.

c. Salah asuhan, salah didik dari orang tua sehingga anak menjadi manja dan lemah mentalnya.

d. Hasrat untuk berkumpul dengan teman-teman senasib dan sebaya menjadi kesukaan untuk meniru-niru.

e. Kecenderungan pembawaan yang patologis.

f. Konflik batin sendiri dan kemudian mempergunakan mekanisme pelarian diri yang irasional. ${ }^{3}$

\section{B. Faktor Eksternal}

Menurut Kartini Kartono Faktor ekstern adalah faktor yang lahir dari luar dari anak faktor ini terdiri dari beberapa hal yaitu:

\section{a. Faktor Lingkungan Keluarga \\ Keluarga mempunyai pengaruh yang sangat besar terhadap}

\footnotetext{
2 Marlina I. Op.Cit., hlm.59.

${ }^{3}$ Kartini Kartono. 1982, Pisikologi Anak, Alumni,

Bandung, hlm 149
} 
seorang anak. Keluarga merupakan lingkungan pertama dalam kehidupan seorang anak dan dari keluarga pula untuk pertama kalinya anak mendapat pendidikan. Hal ini sesuai dengan penjelasan Bimo Walgito mengenai arti keluarga bagi anak adalah merupakan tumpuan pendidikan anak. Keluarga pertamatama bagi anak, dan dari keluarga pulalah anak pertama-tama akan menerima pendidikan, karena keluarga mempunyai peranan penting dalam keluarga. ${ }^{4}$

b. Faktor Lingkungan sekolah $\begin{array}{lr}\text { Bambang } & \text { Muliyono } \\ \text { menegaskan bahwa" } & \text { sekolah }\end{array}$ merupakan tempat pendidikan formal yang mempunyai peranan untuk mengembangkan anak-anak sesuai dengan kemampuannya dan pengetahuannya yang bertujuan agar anak belajar mengembangkan kreatifitas pengetahuan dan keterampilan". ${ }^{5}$

\section{c. Faktor lingkungan pergaulan}

Masyarakat merupakan tempat pendidikan ketiga setelah lingkungan keluarga dan sekolah, karena anak disamping berinteraksi dengan anggota keluarganya juga akan memasuki pergaulan yang lebih besar lagi yaitu lingkungan masyarakat disekitarnya. Pengaruh yang diberikan lingkungan pergaulan besar sekali dan bahkan terkadang dapat membawa perubahan besar dalam kehidupan keluarga.

d. Faktor mass media atau media massa

Mas media ayau yang sering dikenal dengan media massa, seperti majalah, surat kabar, radio, tape, televisi, VCD, dan lain-lain, memberikan pengaruh yang sangat besar bagi kehidupan manusia.

\footnotetext{
${ }^{4}$ Bimo Walgito 1982, Kenakalan Anak, Fakultas Pisikologi UGM Yogyakarta hlm 9

5Bambang Muliyono , 1995. Pendekatan Anlisis Kenakalan Remaja Dan Penangulanganya, Kanisius, Yogyakarta hlm 29
}

\section{Perlindungan Hukum Terhadap Anak Sebagai Pelaku Tindak Pidana}

Masalah perlindungan hukum bagi anak-anak merupakan salah satu sisi pendekatan untuk melindungi anak-anak indnesia. Perlindungan hukum bagi anakanak tertuang dalam Pasal 34 UndangUndang Dasar 1945 yang menegaskan bahwa "Fakir miskin dan anak-anak telantar dipelihara oleh Negara". Ini menunjukkan perhatian serius bagi pemerintah terhadap hak-hak anak dan perlindungannya terutama bagi anak pelaku tindak pidana, maka sangat perlu diadakan perlindungan hukum bagi anak pelaku tindak pidana tersebut yang gunanya adalah sebagai berikut: 1) Anak secara fisik dan mentalnya belum stabil, 2) Untuk menjamin anak terbebas dari hukuman (pidana) yang tidak manusiawi atau merendahkan martabatnya, 3) Untuk menjamin kemerdekaan anak agar tidak dirampas secara tidak sah atau sewenangwenang, 4) Untuk menjamin bahwa pidana (hukuman) hanya diterapkan sebagai Ultimum remedium.

Perlindungan hukum bagi anak pelaku tindak pidana harus benar-benar diperhatikan secara serius. Oleh karena itu perlu diketahui bahwa perlindungan hukum yang harus diberikan pada anak itu adalah perlindungan hukum yang meliputi beberapa konsep sebagai berikut:

1) Konsep Restorative Justice, yaitu sebuah proses dimana semua pihak yang berkepentingan dalam pelanggaran tertentu bertemu bersama untuk menyelesaikan secara bersama-sama bagaimana menyelesaikan akibat dari pelanggaran tersebut demi kepentingan masa depan;

2) Konsep Diversi, yaitu suatu pengalihan penyelesaian kasus-kasus anak yang diduga melakukan tindak pidana tertentu dari proses pidana formal ke penyelesaian damai antara tersangka/terdakwa/pelaku tindak pidana dengan korban yang difasilitasi oleh keluarga dan/atau masyarakat, Pembimbing Kemasyarakatan Anak, Polisi, Jaksa atau Hakim.

\section{KESIMPULAN}

Berdasarkan uraian dari seluruh pembahasan materi hasil penelitian ini, maka dapat disimpulkan: Bahwa faktor penyebab terjadinya Anak melakukan Tindak Pidana 
antara lain faktor ekonomi, pendidikan, lingkungan, lemahnya penegakan hukum dan juga tak lepas dari kelalaian para orang tua dalam mendidik anak. Dapat disimpulkan ada faktor internal dan ekternal. Faktor Internal adalah faktor yang berasal dari dalam diri anak itu sendiri, faktor yang mendorong anak melakukan perbuatan pidana yang berasal dari dirinya sendiri yang meliputi beberapa hal misalnya : salah asuhan, salah didik dari orang tua sehingga anak menjadi manja dan lemah mentalnya, hasrat untuk berkumpul dengan teman-teman senasib dan sebaya menjadi kesukaan untuk meniru-niru dan sebagainyas; Faktor Eksternal diantaranya : Faktor Lingkungan Keluarga, faktor lingkungan sekolah, faktor lingkungan pergaulan dan lain-lain.

Perlindungan hukum bagi anak-anak tertuang dalam Pasal 34 Undang-Undang Dasar 1945 yang menegaskan bahwa "Fakir miskin dan anak-anak telantar dipelihara oleh Negara". Ini menunjukkan perhatian serius bagi pemerintah terhadap hak-hak anak dan perlindungannya terutama bagi anak pelaku tindak pidana, maka sangat perlu diadakan perlindungan hukum bagi anak pelaku tindak pidana tersebut yang gunanya adalah sebagai berikut:

1) Anak secara fisik dan mentalnya belum stabil,

2) Untuk menjamin anak terbebas dari hukuman (pidana) yang tidak manusiawi atau merendahkan martabatnya,

3) Untuk menjamin kemerdekaan anak agar tidak dirampas secara tidak sah atau sewenang-wenang,

4) Untuk menjamin bahwa pidana (hukuman) hanya diterapkan sebagai Ultimum remedium.

Perlindungan hukum bagi anak pelaku tindak pidana harus benar-benar diperhatikan secara serius. Oleh karena itu perlu diketahui bahwa perlindungan hukum yang harus diberikan pada anak itu adalah perlindungan hukum yang meliputi beberapa konsep sebagai berikut:

1) Konsep Restorative Justice, yaitu sebuah proses dimana semua pihak yang berkepentingan dalam pelanggaran tertentu bertemu bersama untuk menyelesaikan secara bersama-sama bagaimana menyelesaikan akibat dari pelanggaran tersebut demi kepentingan masa depan;

2) Konsep Diversi, yaitu suatu pengalihan penyelesaian kasus-kasus anak yang diduga melakukan tindak pidana tertentu dari proses pidana formal ke penyelesaian damai antara tersangka/terdakwa/pelaku tindak pidana dengan korban yang difasilitasi oleh keluarga dan/atau masyarakat, Pembimbing Kemasyarakatan Anak, Polisi, Jaksa atau Hakim.

\section{E. DAFTAR PUSTAKA}

Distia Aviandari, Nining S. Muktamar, Muhammad Jailani, Moch. Riza Zaenal Abidin, Medda Maya Pravita. Analisis Situasi Hak Anak untuk Isu-isu Tertentu. Yogyakarta. Yayasan Sekretariat Anak Merdeka Indonesia (SAMIN). 2010

Djamil, Nasir. Anak Bukan Untuk Dibukum. Catatan Pembahasan UU Sistem Peraadilan Pidana Anak. Jakarta. Sinar Grafika. 2012

Gosita, Arif. Masalah Perlindungan Anak. Jakarta. Akademi Pressindo. 1989

Gultom, Maidin, Prof.Dr.S.H.,M.H.
Perlindungan Hukum Terhadap
Anak dalam Sistem Peradilan
Pidana Anak di Indonesia.
Bandung. PT. Refika Aditama.
2014

Harahap, Yahya. Pembahasan Permasalahan dan Penerapan KUHAP Penyidikan dan Penuntutan. Edisi Kedua. Bandung. Sinar Grafika. 2006

Hidayat, Bunadi. Pemidanaan Anak di bawah umur. Bandung. Alumni 2010.

Ibrahim, Johnny. Teori dan Metodologi Penelitian Hukum Normatif. Malang. Bayumedia. 2006

Kartono, Kartini. Psikologi Anak. Alumni. Bandung. 1979

Muladi dan Barda Nawawi Arief. Teori-Teori Dan Kebijakan Pidana. Bandung. Alumni. 1984

Moeljatno. Perbuatan Pidana dan Pertanggung jawaban Dalam Hukum Pidana. Bina Aksara. Jakarta 1993 
Mulyadi, Lilik. Pengadilan Anak di Indonesia Teori, Praktik dan Permasalahanya. Mandar Maju. Bandung. 2005

Nashriana. Perlindungan Hukum Pidana bagi anak di Indonesia. Jakarta. PT.Rajawali Press. 2011

Rahardjo, Satjipto. Bunga Rampai Permasalaban Dalam Sistem Peradilan Pidana. Pusat Pelayanan Keadilan dan Pengabdian Hukum. Jakarta. 1998.

Saleh, Roeslan. Pikiran-pikiran Tentang Pertanggungjawaban Pidana. Jakarta. Ghalia Indonesia. 1982

Sholehuddin, M. Sistem Sanksi Dalama Hukum Pidana : Ide Dasar Double Track System dan Implementasinya. Jakarta. Rajawali. 2004

Supeno, Hadi. Kriminalisasi Anak Tawaran Gagasan Radikal Peradilan Anak Tanpa Pemidanaan. Jakarta, Gramedia, 2010

Supramono, Gatot. Hukum Acara Peradilan Anak. Jakarta. Djambatan. 2000

Soekanto, Soerjono. Pengantar Penelitian Hukum. Rineka Cipta. Jakarta. 1986.

Wahyudi, Setya. Implementasi Ide Diversi Dalam Pembaruan Sistem Peradilan Pidana Anak di Indonesia. Yogyakarta, Genta Publishing, 2011

Undang-Undang Dasar Republik Indonesia Tahun 1945

Kitab Undang-undang hukum Pidana (KUHP)

Undang-undang Nomor 8 tahun 1981 tentang Kitab Undang-undang Acara Pidana (KUHAP)

Keputusan Presiden Nomor 36 Tahun 1990 tentang tentang Pengesahan Convention Of The Right Of The Child (Konvensi Tentang Hak-Hak Anak) 